\title{
Mekanisme Penetapan Harga Jual Beli Hasil Pertanian Dalam Persfektif Ekonomi Islam di Kabupaten Aceh Utara
}

\author{
Fuadi $^{1}$, Marliyah ${ }^{2 *}$, Falahuddin ${ }^{3}$, Intan Mutia ${ }^{4}$ \\ 1,3,4 Fakultas Ekonomi dan Bisnis, Universitas Malikussaleh, Kota Lhokseumawe \\ Provinsi Aceh, Indonesia. \\ ${ }^{2}$ Universitas Islam Negeri Sumatera Utara, Medan, Provinsi Sumatera Utara, \\ Indonesia.
}

\begin{abstract}
Abstrak. Tujuan penelitian ini untuk melibat para petani mencukupi kebutuban bidup keluarganya dengan hasil panen padi yang diperoleh setiap panennya. Namun belakangan ini para petani merasakan adanya permasalahan yang terjadi dari hasil penjualan panen padi, karena akbir-akhir ini para Agen menetapkan harga penjualan secara tidak adil. penelitian ini menggunakan penelitian Kualitatif dengan tehnik pengumpulan data secara observasi, wawancara dan dokumentasi. Hasil penelitian mendapatkan babwa Mekanisme penetapan harga jual beli hasil pertanian berupa padi oleh Agen kepada petani di Gampong Muling Manyang secara umum belum bisa dikatakan baik karena sebagian besar Agen padi belum menerapkan harga yang sesuai dengan prinsip ekonomi syariah, hanya beberapa pihak yang menetapkan harga sesuai dengan perspektif ekonomi Islam.
\end{abstract}

Kata kunci: Penetapan Harga; Jual Beli; Perspektif Islam.

\begin{abstract}
The purpose of this study is to see that farmers provide for their family's needs with the rice yields obtained for each harvest. But lately, farmers have felt that there are problems that occur from the sale of rice harvests, because lately agents have set sales prices unfairly. This study uses qualitative research with data collection techniques by observation, interviews and documentation. The results of the study found that the mechanism for determining the sale and purchase price of agricultural products in the form of rice by agents to farmers in Muling Manyang Village in general could not be said to be good because most of the rice agents had not applied prices in accordance with sharia economic principles, only a few parties set prices in accordance with Islamic economic perspective.
\end{abstract}

Keywords: Pricing; Buying; Selling; Islamic Perspective.

*Author. Email: fuadi.msm@unimal.ac.id 1..marliyah@uinsu.ac.id 2*, falahuddin@unimal.ac.id 3, intan.160440115@mhs.unimal.ac.id4.

DOI: https://doi.org/10.35870/emt.v5i2.447

Received: 25 June 2021, Revision: 30 July 2021, Accepted: 2 August 2021.

Print ISSN: 2579-7972; Online ISSN: 2549-6204.

Copyright@ 2021. Published by Lembaga Otonom Lembaga Informasi dan Riset Indonesia (KITA INFO dan RISET). 


\section{Pendahuluan}

Manusia sebagai makhluk sosial tidak bisa hidup sendiri, artinya manusia membutuhkan interaksi satu sama lain untuk memenuhi segala kebutuhannya, salah satu bentuk interaksi yang dimaksud yaitu dibidang muamalah. Muamalah merupakan bagian dari hukum islam yang mengatur hubungan antara seseorang dengan orang lain, muamalah juga menyangkut permasalahan hak dan harta yang muncul dari transaksi antara seseorang dengan orang lain atau antara seseorang dengan badan hukum atau antara badan hukum yang satu dengan badan hukum yang lain (Abdullah \& Saebani, 2014).

Dalam ekonomi Islam melakukan suatu usaha harus didasari oleh nilai iman dan akhlak, moral etik bagi setiap aktivitasnya, baik dalam posisi sebagai konsumen, produsen, maupun distributor. Dalam Islam perdagangan harus dilakukan secara baik, dan sesuai dengan prinsip-prinsip ekonomi syariah, di dalam Islam juga telah dilarang untuk mengambil keuntungan yang berlebihan. Suatu perdagangan yang tidak jujur atau dapat merugikan orang lain diharamkan untuk melakukannya.

Dalam jual beli atau dikenal dengan istilah harga, penentuan harga merupakan salah satu aspek terpenting dalam kegiatan jual beli. Harga menjadi sangat penting diperhatikan, mengingat harga menentukan terjual atau tidaknya suatu produk dalam jual beli (Rosmalia, 2017). Jika salah dalam menentukan harga maka akan berakibat fatal dalam produk yang ditawarkan nantinya. Harga merupakan satu-satunya unsur dalam jual beli yang menghasilkan keuntungan dan pendapatan penjualan barang dan jasa. Oleh karena itu, harga yang ditetapkan penjual harus sebanding dengan penawaran nilai kepada konsumen. Harga juga merupakan salah satu bagian yang sangat penting dalam pemasaran suatu produk karena harga adalah salah satu dari empat aspek pemasaran. Harga adalah suatu nilai tukar dari produk barang maupun jasa yang dinyatakan dalam satuan moneter.

Kebijakan harga pada komoditas pertanian salah satunya beras berpengaruh pada stabilitas harga padi yang merupakan tanaman pangan, penentuan harga padi tergantung pada perkembangan nilai tukar petani pada subsektor tanaman pangan.

Penetapan harga tidak hanya ditentukan oleh dua pihak antara penjual dan pembeli, namun juga harus melihat stabilisasi harga pasar yang ditetapkan oleh pemerintah, tetapi ada juga penetapan harga yang hanya ditetapkan oleh beberapa pihak yang berlaku sebagai penjual dan pembeli tanpa mengikuti harga yang diberlakukan oleh pemerintah atau harga yang sedang beredar di pasaran, agar memperoleh keuntungan yang lebih bagi untuk salah satu pihak.

Fenomena yang terjadi di Gampong Mulieng Manyang kecamatan Kuta Makmur Kabupaten Aceh Utara yaitu para petani menjual hasil pertaniannya berupa padi kepada Agen padi yang juga berprofesi sebagai penjual pupuk untuk pemeliharaan padi, dengan harga beli dari Agen yang berbeda dengan harga yang beredar di pasaran dan juga harga yang ditetapkan oleh pabrik beras, hal tersebut terjadi karena minimnya akses pengetahuan petani tentang harga dan keterikatan petani terhadap Agen dalam penjualan hasil panen padi, dimana para petani terkait hutang piutang dengan Agen. sehingga hal tersebut merugikan petani dimana para agen yang datang langsung ke sawah ketika panen untuk membeli padi menetapkan harga yang rendah. Hal tersebut menyebabkan para petani di gampong mulieng manyang mengalami kesulitan ekonomi untuk mencukupi biaya hidup dikarenakan di gampong muling manyang sumber penghasilan masyarakat didasarkan pada hasil pertanian padinya.

\section{Literature Review}

\section{Mekanisme penetapan harga}

Mekanisme harga adalah proses yang berjalan atas dasar gaya tarik menarik antara produsen dan konsumen baik dari pasar output (barang) ataupun input (faktor-faktor produksi). Penetapan harga dilakukan untuk mendapatkan hasil dari penjualan produk ataupun jasa tertentu yang dihasilkan dan dipasarkan untuk memperoleh sejumlah laba atau keuntungan.

Menurut Ibn Taymiyah (dalam Matrani, 2008) 
harga adalah sejumlah uang yang menyatakan nilai tukar suatu unit benda tertentu.

\section{Jual Beli}

Jual beli merupakan istilah yang dapat digunakan untuk menyebut dari dua sisi transaksi yang terjadi sekaligus, yaitu menjual dan membeli. jual beli adalah tukar menukar harta dengan harta, biasanya berupa barang dengan uang yang dilakukan secara suka sama suka dengan akad tertentu dengan tujuan untuk memiliki barang tersebut (Mujiatun, (2013).

Jual beli menurut syara' adalah mempermilikkan suatu harta (pada orang lain) dengan cara tukar menukar sesuatu dengan mendapat ijin syara', atau mempermilikkan manfaat selamanya yang diperbolehkan syara' yang melakukan pembayaran harga dengan memberi harta berupa uang sesuai dengan nilai dari barang yang diperjualbelikan dan juga adanya manfaat yang dapat digunakan dari barang tersebut (Purnama Sari, 2019; Fathul Qarib:30 dalam Abduroman, Putra, \& Nurdin, 2020).

Menurut Abdul Rahman Ghazali (dalam Azizah, 2017; Hasnah, 2013) mengemukakan Jual beli atau perdagangan dalam istilah fiqih disebut al-bai' yang menurut etimologi berarti menjual atau mengganti. Jual beli sebagai sarana tolong menolong antara sesama umat manusia mempunyai landasan yang kuat dalam Al-Qur'an dan sunnah Rasulullah SAW. Jual beli merupakan suatu akad, dan dipandang sah apabila telah memenuhi rukun dan syarat jual beli.

1) Dasar Hukum Jual Beli

Landasan atau dasar hukum mengenai jual beli disyariatkan berdasarkan Al-Qur'an, Hadist Nabi dan Ijma'. Pelaksanaan transaksi jual beli telah menetapkan tata aturan yang secara detail disebutkan dalam ilmu fiqih muamalah.

2) Al-Qur'an

Adapun dasar hukum yang menjelaskan tentang diperbolehkannya jual beli dijelaskan didalam Al-Qur'an surat AlBaqarah ayat 275 yang artinya "Orangorang yang makan (mengambil) riba tidak dapat berdiri melainkan seperti berdirinya orang yang kemasukan syaitan lantaran (tekanan) penyakit gila. Keadaan mereka yang demikian itu, adalah disebabkan mereka berkata (berpendapat), Sesungguhnya jual beli itu sama dengan riba, padahal Allah telah menghalalkan jual beli dan mengharamkan riba, orang-orang yang telah sampai kepadanya larangan dari Tuhannya, lalu terus berhenti (dari mengambil riba), maka baginya apa yang telah diambil dahulu (sebelum datang larangan), dan urusan (terserah) kepada Allah, orang yang kembali (mengambil riba), maka orang itu adalah penghunipenghuni neraka, mereka kekal di dalamnya.

Ayat di atas menjelaskan tentang dasar kehalalan hukum jual beli dengan baik dan melarang praktek jual beli yang mengandung riba.

3) Hadist Nabi

Berkaitan dengan jual beli, Rasulullah SAW pernah ditanya oleh salah satu sahabatnya mengenai pekerjaan yang baik, maka jawaban beliau ketika itu adalah jual beli. Peristiwa ini sebagaimana dijelaskan dalam hadis yang artinya:

"Dari Rifa'ah bin Rafi' ra. Ia berkata, bahwasanya Rasulullah SAW pernah ditanya: Usaha apakah yang paling halal itu (ya Rasulullah)? Maka beliau menjawab, "Yaitu pekerjaan seseorang dengan tangan nya sendiri dan setiap jual beli itu baik"(HR. Imam Bazzar. Imaam Hakim meyahihkannya dari Rifa'ah Ibn Rafi'). (Syafe \& Muamalat, 2004; Rasjid, 2012)

Berdasarkan hadist diatas, maka jelaslah bahwa hukum jual beli adalah jaiz (boleh). Namun tidak menutup kemungkinan perubahan status jual beli itu sendiri, semuanya tergantung pada terpenuhi atau tidaknya syarat dan rukun jual beli. (Shobirin, 2016).

\section{Hubungan Mekanisme Penetapan Harga Terhadap Jual Beli}

Secara umum penetapan harga suatu barang berpengaruh terhadap keberhasilan terjualnya suatu produk. Apabila orang-orang memperjual belikan barang dagangannya dengan cara-cara yang biasa dilakukan, tanpa adanya pihak yang dirugikan dan merasa terdzalimi, jika adanya 
kenaikan harga itu disebabkan oleh factor supply dan demand pasar tidak seimbang, dimanaberkurangnya jumlah persediaan barang (supply) ataupun bertambahnya permintaan barang dari konsumen (demand), maka harga yang beredar di pasar harus sesuai dengan ekonomi yang sedang berkembang. (Ibn Taymiyah dalam Matrani, 2008; Salwah, 2019; Khasanah, 2018; Kawa, 2018).

\section{Hipotesis}

Berdasarkan data empiris diatas maka dapat diajukan hipotesis adalah sebagai berikut:

H1 : Diduga Harga yang beredar tidak pasaran berpengaruh terhadap mekanisme penetapan harga jual beli hasil pertanian di gampong muling manyang.

H2 : Diduga Jual beli berpengaruh terhadap mekanisme penetapan harga jual beli hasil pertanian di gampong muling manyang.

\section{Metodologi Penelitian}

\section{Objek Dan Lokasi Penelitian}

Objek yang menjadi penelitian penulis yaitu Mekanisme penetapan harga jual beli hasil pertanian berupa padi, dari petani yang dijual kepada Agen. Lokasi penelitian yang di ambil adalah di gampong muling manyang kecamatan kuta makmur kabupaten aceh utara

\section{Subjek dan Objek}

Subjek adalah target populasi yang memiliki karakteristik tertentu yang diterapkan peneliti untuk di pelajari dan kemudian ditarik kesimpulannya (Sugiyono, 2010). Subjek dalam penelitian ini adalah petani yang memiliki lahan sawah di gampong muling manyang dan menggarap tanahnya sendiri berjumlah 9 orang, Agen padi yang berperan sebagai pembeli padi dari petani berjumlah 3 orang, dan konsumtif yaitu konsumen yang membeli beras dan tidak memiliki lahan sawah dan juga padi berjumlah 3 orang.

\section{Hasil dan Pembahasan}

Berdasarkan hasil penelitian mekanisme penetapan harga jual beli berpengaruh terhadap harga suatu barang, dengan metode dan tujuan tertentu terhadap penetapan harga agar memperoleh keuntungan dari suatu produk yang dipejualbelikan. Jual beli berpengaruh terhadap penentuan harga suatu produk, harga yang adil dan juga yang seimbang dimana pembeli dan penjual sama-sama memperoleh manfaat. Selain itu Hasil penelitian ini menunjukkan bahwa penetapan harga jual beli padi oleh para Agen kepada petani di Desa muling manyang belum sesuai dengan perspektif ekonomi islam, para Agen tidak transparan dalam memberitahukan harga yang beredar dipasaran terhadap petani, petani juga mempunyai keterikatan hutang piutang terhadap Agen yang menyebabkan petani terpaksa menjual hasil panen nya kepada Agen tertentu meskipun harga yang ditetapkan sangat murah.

Hasil penelitian peneliti dengan hubungan penelitian yang dilakukan oleh peneliti sebelumnya bahwa terjadi kedzaliman atau tidak sesuai-nya transaksi dengan perspektif ekonomi islam pada mekanisme penetapan harga saat jual beli dilakukan dimana penjual terpaksa menjual hasil panennya dengan harga rendah, harga padi dibayarkan setelah proses distribusi padi dilakukan oleh si pembeli kepada pabrik. petani memperoleh bukti transaksi berupa bon yang berisi informasi tentang harga dan jumlah dari hasil panen yang akan diterima.

Kaitan lainnya terdapat pada sistem penetapan harga belum dilakukan secara Adil terutama bagi para produsen yang menetapkan harga harus sesuai dengan permintaan dan penawaran barang yang sesuai beredar di pasaran jangan menetapkan harga sepihak hanya untuk memperoleh keuntungan yang lebih dan juga dilarang dalam islam. Mekanisme penetapan harga jual suatu barang didasari oleh permintaan dan penawaran barang yang beredar di pasaran, untuk memperoleh harga yang adil dan tidak ada pihak yang merasa dirugikan, baik itu si penjual atau pun si pembeli. 


\section{Kesimpulan}

1) Mekanisme penetapan harga jual beli hasil pertanian berupa padi oleh Agen kepada petani di Gampong Muling Manyang secara umum belum bisa dikatakan baik karena sebagian besar Agen padi belum menerapkan harga yang sesuai dengan prinsip ekonomi syariah, hanya beberapa pihak yang menetapkan harga sesuai dengan perspektif ekonomi islam.

2) Konsep ekonomi islam mengatur kehidupan manusia dari segi muamalah. Tujuan dengan adanya ekonomi syariah untuk meluruskan transaksi-transaksi yang tidak memberikan kemaslahatan bagi umat muslim. Tujuan adanya transaksi jual beli adalah untuk mencari rahmat Allah Swt dan keberkahannya, bukan untuk meningkatkan kekayaan atau memaksimalkan laba/keuntungan. Mekanisme penetapan harga jika ditentukan oleh muafakat antara kedua belah pihak dan mengikuti stabilisasi harga pasar maka semua transaksi jual beli yang dilakukan akan mendapatkan keberkahan di dunia maupun di akhirat.

\section{Daftar Pustaka}

Abdullah, B., \& Saebani, B. A. (2013). Perkawinan dan Perceraian Keluarga Muslim. Bandung: Pustaka Setia.

Abduroman, D., Putra, H. M., \& Nurdin, I. (2020). Tinjauan Fiqih Muamalah Terhadap Jual Beli Online. Ecopreneur: Jurnal Program Studi Ekonomi Syariah, 1(2), $35-48$.

Azizah, L. (2017). Pandangan Wahbah Az-Zuh \{Aili $>>$ Terhadap Pematokan Harga Komoditi Perdagangan (Doctoral dissertation, IAIN).

Depak Ri. Al-Quran dan Terjemahan. (2004) : Edisi baru. Surabaya : Mekar Surabaya
Hasnah, H. (2013). Penetapan Harga Jual Dalam Perspektif Ekonomi Islam (Studi Kasus pada Rumah Makan Prasmanan Arby di Makassar) (Doctoral dissertation, Universitas Islam Negeri Alauddin Makassar).

Husain Syahatah dan Siddiq M. Al-Amin Adh Dharir. (2005). Transaksi dan Etika Bisnis Islam Jakarta: Visi Insani Publishing.

Kawa, Y. (2018). Penetapan Harga Komoditi Hasil Pertanian Bagi Pedagang Di Pasar Tradisional Srengat Blitar Ditinjau Dari Teori Penetapan Harga Dalam Ekonomi Islam. Institutional Repository of IAIN Tulungagung.

Khasanah, U. (2018). Tinjanan Ekonomi Islam Terbadap Penetapan Harga Cabai di Pasar Plaza Bandarjaya Lampung Tengah (Doctoral dissertation, IAIN Metro).

Matrani, M. A. (2008). Pemikiran Ibnu Taimiyyah tentang Mekanisme Pasar dalam Ekonomi Islam (Doctoral dissertation, Universitas Muhammadiyah Surakarta).

Mujiatun, S. (2013). Jual Beli dalam Perspektif Islam: Salam dan Istisna'. Jurnal Riset Akuntansi dan Bisnis, 13(2).

Purnama Sari, W. (2019). Jual Beli Gabah Padi Perspektif Etika Bisnis Islam (Studi Kasus Desa Durian Sebatang Kecamatan Kedurang Kabupaten Bengkulu Selatan) (Doctoral dissertation, Iain Bengkulu).

Rasjid, S. (2012). Fiqh Islam (Hukum Fiqh Islam). Bandung: Sinar Baru Algesindo.

Rosmalia, D. (2017). Praktek Jual Beli Hasil Pertanian Secara Langsung dalam Tinjauan Ekonomi Islam (Studi Kasus Jual Beli Sayur Mayur di Desa Gunung Perak Kecamatan Sinjai Barat Kabupaten Sinjai) (Doctoral dissertation, Universitas Islam Negeri Alauddin Makassar). 
Salwah, S. (2019). Mekanisme Penetapan Harga dalam Perspektif Ekonomi Islam (Studi Kasus pada Pedagang Jeruke di Padanglampe Kabupaten Pangkep) (Doctoral dissertation, Universitas Islam Negeri Alauddin Makassar).

Shobirin, S. (2016). Jual Beli Dalam Pandangan Islam. BISNIS: Jurnal Bisnis dan Manajemen Islam, 3(2), 239-261.
Sugiyono, S. (2010). Metode penelitian kuantitatif dan kualitatif dan R\&D. Alfabeta Bandung.

Syafe, I., \& Muamalat, R. F. (2004). Bandung: CV. Pustaka Setia. 